\title{
Floodplain sediment from a 100-year-recurrence flood in 2005 of the Ping River in northern Thailand
}

\author{
S. H. Wood ${ }^{1}$ and A. D. Ziegler ${ }^{2,3}$ \\ ${ }^{1}$ Department of Geosciences, Boise State University, Boise, Idaho 83702 USA \\ ${ }^{2}$ Geography Department, University of Hawaii, Honolulu, Hawaii 96822, USA \\ ${ }^{3}$ Geography, National University of Singapore, Singapore
}

Received: 1 October 2007 - Published in Hydrol. Earth Syst. Sci. Discuss.: 18 October 2007

Revised: 17 April 2008 - Accepted: 3 June 2008 - Published: 11 July 2008

\begin{abstract}
The tropical storm, floodwater, and the floodplainsediment layer of a 100-year recurrence flood are examined to better understand characteristics of large monsoon floods on medium-sized rivers in northern Thailand. Storms producing large floods in northern Thailand occur early or late in the summer rainy season (May-October). These storms are associated with tropical depressions evolving from typhoons in the South China Sea that travel westward across the Indochina Peninsula. In late September, 2005, the tropical depression from Typhoon Damrey swept across northern Thailand delivering $100-200 \mathrm{~mm} /$ day at stations in mountainous areas. Peak flow from the $6355-\mathrm{km}^{2}$ drainage area of the Ping River upstream of the city of Chiang Mai was $867 \mathrm{~m}^{3} \mathrm{~s}^{-1}$ (river-gage of height $4.93 \mathrm{~m}$ ) and flow greater than $600 \mathrm{~m}^{3} \mathrm{~s}^{-1}$ lasted for 2.5 days. Parts of the city of Chiang Mai and some parts of the floodplain in the intermontane Chiang Mai basin were flooded up to $1-\mathrm{km}$ distant from the main channel. Suspended-sediment concentrations in the floodwater were measured and estimated to be 1000 $1300 \mathrm{mg} \mathrm{l}^{-1}$.

The mass of dry sediment $\left(32.4 \mathrm{~kg} \mathrm{~m}^{-2}\right)$, measured over a $0.32-\mathrm{km}^{2}$ area of the floodplain is relatively high compared to reports from European and North American river floods. Average wet sediment thickness over the area was $3.3 \mathrm{~cm}$. Sediment thicker than $8 \mathrm{~cm}$ covered 16 per cent of the area, and sediment thicker than $4 \mathrm{~cm}$ covered 44 per cent of the area. High suspended-sediment concentration in the floodwater, flow to the floodplain through a gap in the levee afforded by the mouth of a tributary stream as well as flow over levees, and floodwater depths of $1.2 \mathrm{~m}$ explain the relatively large amount of sediment in the measured area.
\end{abstract}

Correspondence to: S. H. Wood

(swood@boisestate.edu)
Grain-size analyses and examination of the flood layer showed about $15-\mathrm{cm}$ thickness of massive fine-sandy silt on the levee within $15-\mathrm{m}$ of the main channel, sediment thicker than $6 \mathrm{~cm}$ within $200 \mathrm{~m}$ of the main channel containing a basal coarse silt, and massive clayey silt beyond $200 \mathrm{~m}$. The massive clayey silt would not be discernable as a separate layer in section of similar deposits. The fine-sand content of the levee sediment and the basal coarse silt of sediment within $200 \mathrm{~m}$ of the main channel are sedimentological features that may be useful in identifying flood layers in a stratigraphic section of floodplain deposits.

\section{Introduction}

Infrequent large floods usually occur in northern Thailand late in the May-October rainy season. Although the MayOctober rainfall is dominated by masses of moist air moving northeast from the Indian Ocean, large floods are typically associated with tropical depressions moving westward from the South China Sea (Fig. 1). Three flood events on the Ping River in August and September, 2005 flooded parts of Chiang Mai city and other floodplain areas within $1 \mathrm{~km}$ of the main channel. The first flood (14-16 August) was the result of a heavy monsoon rainstorm associated with a low-pressure trough moving westward across northern Thailand. Chiang Dao reported $200 \mathrm{~mm}$ of rain for 13 August. Flooding and mudslides affected a large area, including Chiang Mai, Chiang Rai, Phayao and Mae Hong Song Provinces (Fig. 2). A second, smaller flood (20-22 September) was associated with tropical storm Vincente as it weakened to a tropical depression, again traveling westward across Indochina from the South China Sea.

Published by Copernicus Publications on behalf of the European Geosciences Union. 


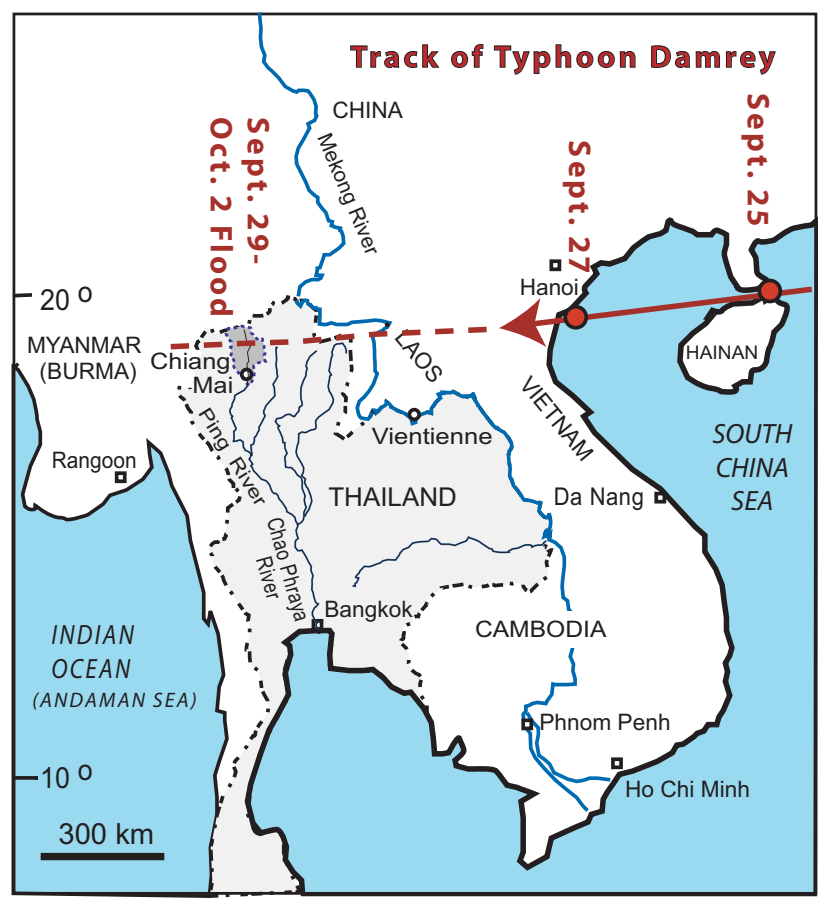

Fig. 1. Location of the Ping River showing the track of the tropical depression that evolved from Typhoon Damrey. Dark shaded area is drainage area upstream of Chiang Mai and the study area.

The third and largest flood (29 September-2 October) reached a flow of $867 \mathrm{~m}^{3} \mathrm{~s}^{-1}$ at Chiang Mai city. This event was a result of Typhoon Damrey, which made landfall on Hainan on 25 September and swept westward across the Indochina Peninsula as a tropical depression (Figs. 1 and 3). In the upper Ping River drainage heavy rainfall occurred from 27 September until 30 September. The storm rained $120 \mathrm{~mm}$ on 27 September at Phrao, and then $200 \mathrm{~mm}$ on 30 September in the mountains $12 \mathrm{~km}$ southwest of Chiang Dao (Fig. 4). Rainfall at the Angkhang Meteorological Center in the mountains west of Fang measured 200 millimeters (Chiang Mai News, 8 October 2006). Scattered small slope failures occurred during the storm along many of the roads. Flash flooding and mudslides occurred in the same provinces that were hit in August, and additionally in the Lampang and Phrae Provinces (Fig. 2). The cities of Chiang Mai and Lampang were partly flooded. The main storm passed north of Chiang Mai. Heavy rainfall apparently occurred mostly in the mountainous areas along a $100-\mathrm{km}$ wide swath of the west-traveling storm path.

The 27-30 September storm is characteristic of storms producing major floods with greater than 10-year recurrence in northern Thailand. Heavy rainfall occurs along a westerlytraveling storm path after landfall of a South China Sea typhoon. These storms are limited in their north-south extent, and often occur in August and September. The 14 September 1994 flood on the Ping River, for example, was associ-

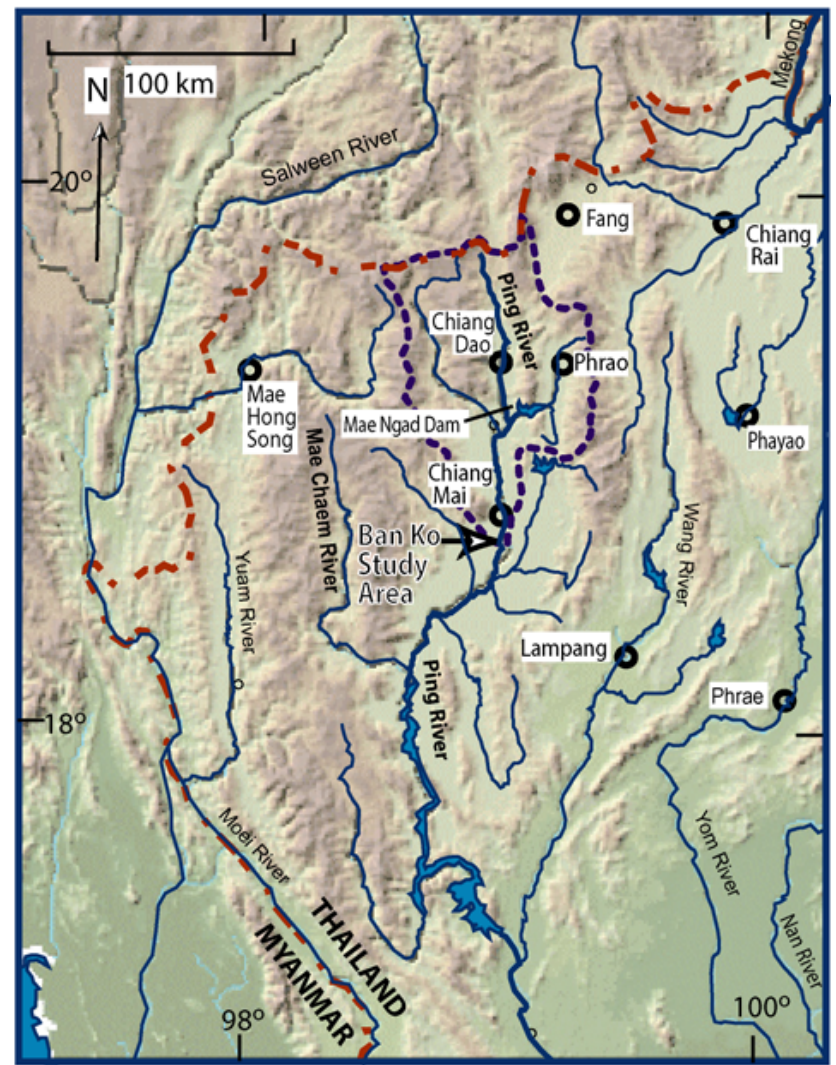

Fig. 2. Outline of the Ping River drainage (dotted line) upstream of the study area showing the location of the dam on the Nam Mae Ngad which regulates flow from $1 / 5$ of the drainage. Labeled cities are those which reported major flooding 12 August-4 October 2005.

ated with the westward traveling storm from Typhoon Harry. Kidson et al. (2005) indicate that the 12 August 2001 storm produced a 16-year recurrence flood peak on the Mae Chaem River, and the BBC news (2001) reported this storm caused disastrous flooding in Vietnam and in north-central Thailand associated with Typhoon Usagi. Such storms, however, are not restricted to the late summer monsoon. The 2123 May 2006 storm was a low-pressure system that produced heavy rainfall, disastrous flooding and mudslides in the Da Nang Province of Vietnam and in north-central Thailand (Asian Disaster Preparedness Center, 2006). This weather system occurred 5 days after the eye of Typhoon Chanchu changed its track from NW to NE about $1000 \mathrm{~km}$ off the coast of Vietnam, apparently a result of unsettled atmospheric conditions at the onset of the summer monsoon. In all these events, the source areas of rainfall producing disastrous flooding depends upon the north-south position of the westward traveling tropical depression.

Because sediment concentrations during large flows in the Ping River typically exceed $500 \mathrm{mg}^{-1}$ the potential for substantial "silt" deposition during flooding is high—although this phenomenon has never been documented in detail. Most 
studies of sediment deposition during individual big floods have been on European and North American large rivers that commonly have suspended sediment loads less than $500 \mathrm{mg}$ $1^{-1}$ (Asselman and Middelkoop, 1995; Gomez et al., 1995; Leece et al., 2004). Understanding sedimentation from infrequent large floods on moderate-sized southeast Asian rivers is of interest because sediment concentrations can be quite high. Depositional evidence of these events, however, is often short-lived on account of lush vegetation and frequent cultivation of the floodplain areas. It is intuitive to think that the thickness of floodplain sedimentation is related to the duration of the overbank stage and the concentration of suspended sediment (Moody and Troutman, 2000). In this work we measured the thickness of mud sediment deposited on the floodplain of the Ping River following 29 September2 October, 2005 flood event. An objective of our study was to describe sediment of a known flood. These descriptions will help interpretation of floodplain stratigraphy in the area (e.g. Wood and others, in press). We examined the pattern of sediment thickness over a small flooded area, photodocumented the appearance of the flood layer, and studied the grain-size variation of the layer.

\section{Study area}

The Ping River drains a mountainous area of northern Thailand with steep hills up to elevation 1500 to $2000 \mathrm{~m}$, and valleys at 330 to $500 \mathrm{~m}$ (Fig. 2). The Ping River basin is underlain by older Paleozoic gneissic granites, Paleozoic sediments and volcanics, Mesozoic granitic rocks, and Tertiary continental basin-fill sediments (Hess and Koch, 1979; Rhodes et al., 2005). The lowlands are underlain by alluvial fan, terrace, and floodplain deposits (Margane and Tatong, 1999). Upland areas and older terrace and fans have deep weathering profiles of saprolite one to tens of meters thick overlain by red-yellow argillic soil horizons one to several meters thick. Surface soils are dark brown loams up to $25 \mathrm{~cm}$ thick. Valley bottoms are mostly clayey silt with gleyed soils in the paddy areas.

It was estimated that 70 per cent of northern Thailand highlands were covered by subtropical forest in 1960. Logging and clearing for agriculture had reduced forest cover to $43 \%$ by 1998 (Charuppat, 1998; Thomas et al., 2002). Forested hills are mostly covered by 2 nd growth deciduous and evergreen forest with bamboo thickets. Only a few steeper areas have original canopied forests with tall trees (20-30 m high). Many hillsides are partly cleared and have many trails and roads (Ziegler et al., 2004). Corn and upland rice are the common crops of shifting swidden cultivation of the hillsides. Agricultural systems are currently shifting to permanent irrigated crops, flower farms, and commercial greenhouses in many hill areas.
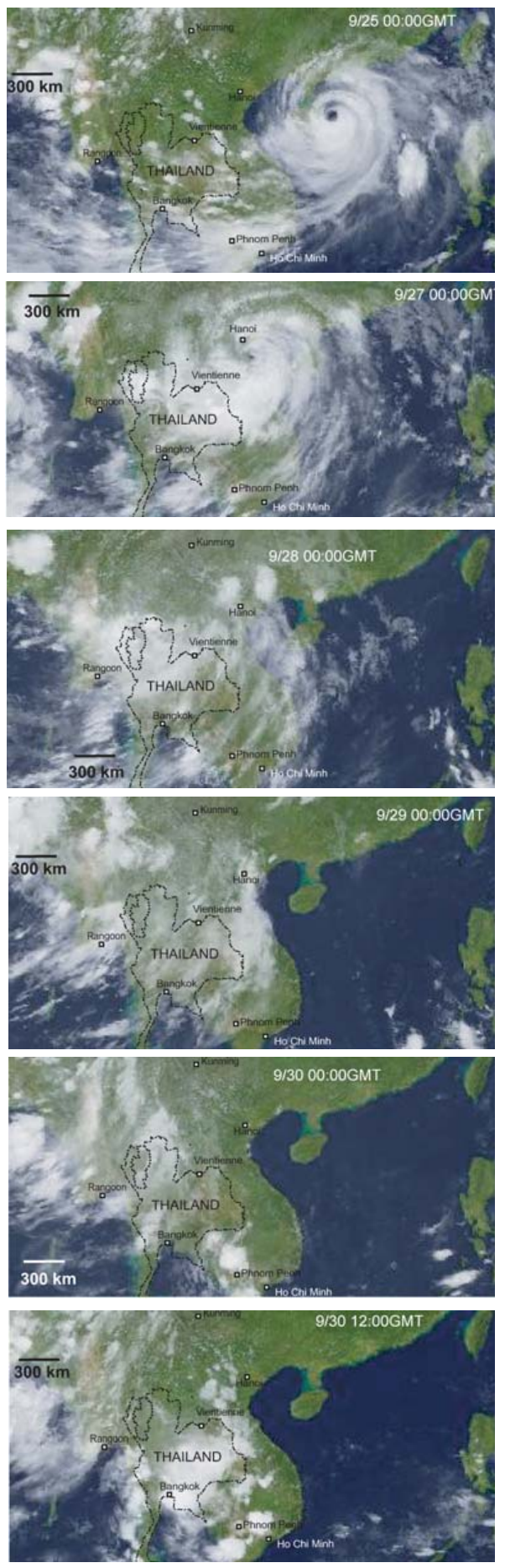

Fig. 3. Satellite images showing the westward traveling tropical storm from Typhoon Damrey, 25-30 September 2005. From archive of EEI-lab, Kochi University, MTSAT IR IR1 JMA. Thailand local time is $7 \mathrm{~h}$ later than GMT. 

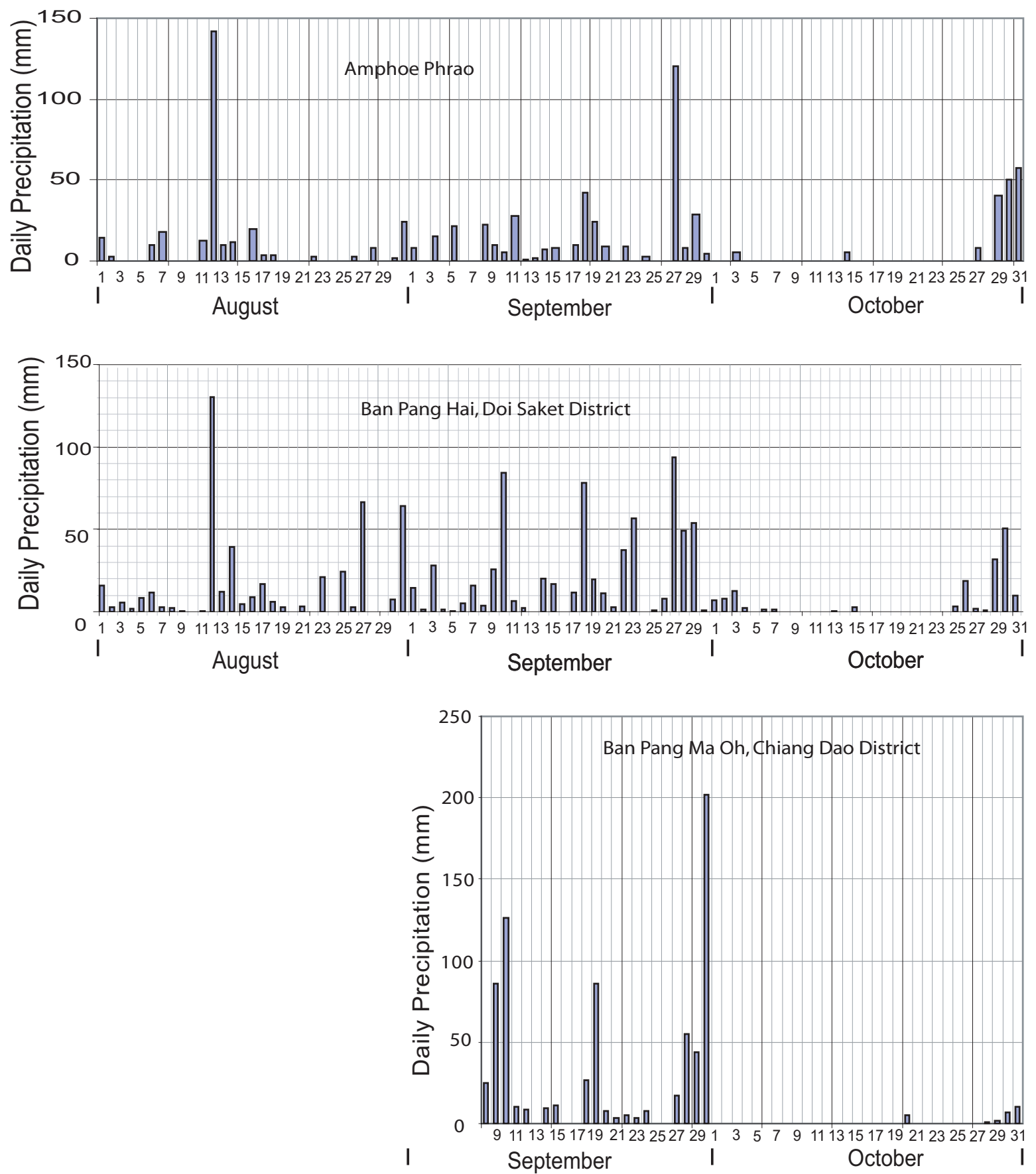

Fig. 4. August-October, 2005 daily precipitation at stations within the Ping River basin: Amphoe Phrao $\left(19^{\circ} 21.0^{\prime} \mathrm{N}, 99^{\circ} 11.0^{\prime} \mathrm{E}, 410-\mathrm{m}\right.$ elevation); Ban Pang Hai, Doi Saket District (18 57.4’ N, 98 49.1'E, 810-m elevation, 25 km northwest of Chiang Mai); Ban Pahng Ma Oh Watershed Research Station, Mae Na Subdistrict, Chiang Dao District (19 $16.3^{\prime} \mathrm{N}, 98^{\circ} 54.4^{\prime} \mathrm{E}, 1100-\mathrm{m}$ elevation, $12 \mathrm{~km}$ southwest of Chiang Dao, data available since 8 September 2005). 
The river courses $58 \mathrm{~km}$ through the intermontane Chiang Mai basin, with a floodplain about $3 \mathrm{~km}$ wide, extending about 1 to $1.5 \mathrm{~km}$ to either side of the river, beyond which are alluvial benches that rise 5 to $10 \mathrm{~m}$ above the floodplain. The lowlands consist of fruit orchards, paddy-rice fields and urban areas and villages. The river flows through the Chiang Mai basin in a single alluvial channel of low sinuosity using terminology of Leopold and Wolman (1957). The channel is 40 -to-70-m wide. It is largely a sand-bed river along this reach. Leveed banks are typically 3 to $4 \mathrm{~m}$ above the channel bed. Many levees are utilized for narrow one-and-twolane surfaced roadways. Levees are 0.5 to 1 meter above the floodplain. River gradient through the Chiang Mai basin, determined from 1:50,000, maps is $0.0006 \mathrm{~m} \mathrm{~m}^{-1}$.

The average annual precipitation for the Ping River basin above Chiang Mai is estimated at $1200 \mathrm{~mm}$ based on maps by Sukasem and Chotiwanwilat (1987) who examined the 1952-1984 record from stations mostly in the low valleys. Northern Thailand has alternating dry and wet seasons with $90 \%$ of rainfall occurring between May and November. Year to year precipitation is highly variable. Annual precipitation in areas above 1000-m elevation often exceeds $1500 \mathrm{~mm}$.

The Ping River above gage P.1 has a drainage area of $6355 \mathrm{~km}^{2}$ (Fig. 2). Of this drainage area, $1 / 5$ is regulated by the Mae Ngad Dam (active volume of 90 million $\mathrm{m}^{3}$, total volume of 302 million $\mathrm{m}^{3}$ ), which has controlled drainage from about $1300 \mathrm{~km}^{2}$ since 1985 .

The average annual flow of the Ping River (1921-1985) is $62 \mathrm{~m}^{3} \mathrm{~s}^{-1}$, but ranges from 22 to $135 \mathrm{~m}^{3} \mathrm{~s}^{-1}$ over that period of record (Royal Irrigation Department, 1937-1985). Using these values the calculated mean annual runoff coefficient for the Ping River above Chiang Mai is $25.6 \%$, similar to values calculated by Alford (1992).

The Ban Ko village study area (Fig. 2) is located in the Chiang Mai basin, $12 \mathrm{~km}$ downstream from the P.1 stream gage at the Nawarat Bridge in the city of Chiang Mai. No major tributaries or diversions exist between the P.1 gage and Ban Ko ; therefore, this gage is a good measure of flow to the study area.

Below the study area, the river continues through mountainous terrain to the Bhumipol Dam. Below the dam, the river flows another $100 \mathrm{~km}$ to the Central Plain, and then joins the Chao Phrao River which flows to the Gulf of Thailand at Bangkok.

\section{Flood hydrographs, flood recurrence and flood his- tory}

In the first version of this paper we used flood-flow data provided by the Royal Irrigation Department based upon the 2004 stage-discharge curve for the P.1 gage (Fig. 5b). After the flood, the Royal Irrigation Department re-surveyed the channel and revised the rating curve, which significantly increased the flood flows by about $100 \mathrm{~m}^{3} \mathrm{~s}^{-1}$. The revised
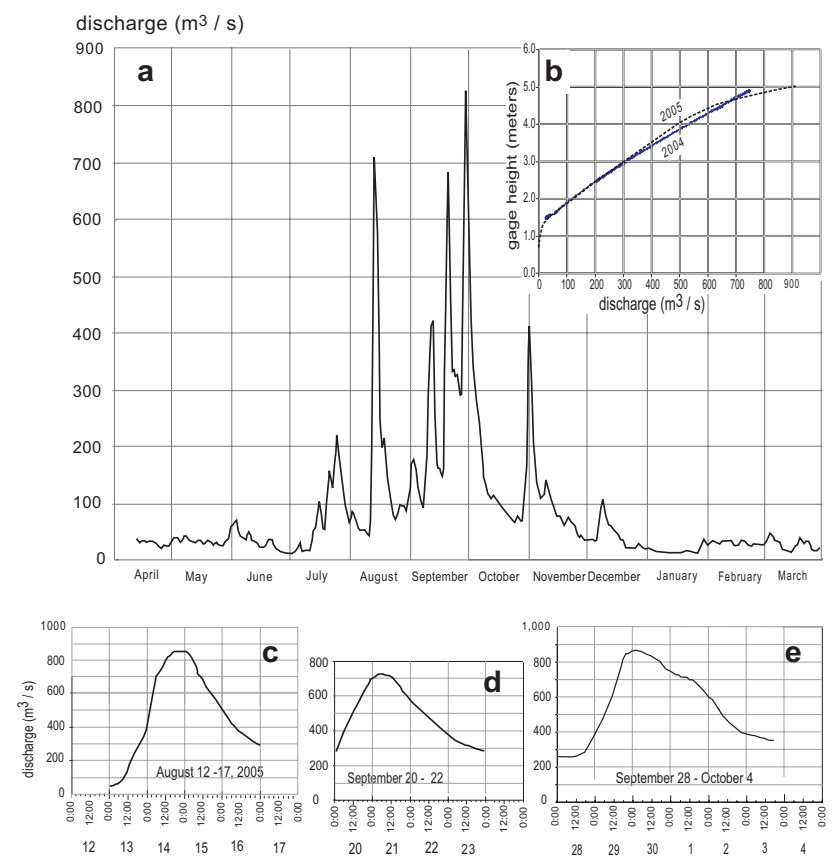

Fig. 5. Hydrographs of daily-mean flow readings at the P.1 gage at Narawat Bridge in Chiang Mai. (a) the mean-daily flow 2005 hydrograph, (b) Stage-flow relationship, (c) hourly flow - 12-17 August, (d) hourly flow - 20-22 September, and (e) hourly flow 29 September-2 October, (Data from Royal Irrigation Department, Hydrology and Water Management Office).

peak flows on 14 August of $850 \mathrm{~m}^{3} \mathrm{~s}^{-1}$ (4.90-m stage) and on 30 September of $867 \mathrm{~m}^{3} \mathrm{~s}^{-1}$ (4.93-m stage) are the largest in the 1921-2007 flood-history record (Figs. 5 and 6). These flood peaks are now considered 100-yr recurrence events. Prior to 2005, the largest flood in recent history occurred in 1973 , with a stage of $4.17 \mathrm{~m}$ and a peak flow of $726 \mathrm{~m}^{3} \mathrm{~s}^{-1}$. The mean annual flood peak is from 300 to $400 \mathrm{~m}^{3} \mathrm{~s}^{-1}$; and the 10 -year peak is estimated to be $590 \mathrm{~m}^{3} \mathrm{~s}^{-1}$ (Fig. 6). Before 1921, little is known of the flood history of the Ping River. A large flood in 1831 (Tangtham et al., 1999) is believed to have caused major channel changes and sedimentation over the 13th Century city of Wiang Kum Kam, $6 \mathrm{~km}$ upstream from the Ban Ko village study area (Velechovsky et al., 1987; Wood et al., 2004).

In the Mae Chaem River catchment $\left(3853 \mathrm{~km}^{2}\right.$ area), a sub-catchment of the Ping River downstream of our study area (Fig. 2), Kidson et al. (2005) identified paleoflood evidence suggesting a previous peak discharge of $2480 \mathrm{~m}^{3} \mathrm{~s}^{-1}$. This peak greatly exceeds that of the 1961 flood $\left(980 \mathrm{~m}^{3} \mathrm{~s}^{-1}\right)$, the largest flood peak in the contemporary (1953 to 2007) Mae Chaem record. Their paleoflood work also suggests the potential for larger flood peaks on the Ping River than those predicted by traditional floodfrequency models. As the Ping River catchment at Chiang Mai is $160 \%$ larger than the Mae Chaem catchment, the 


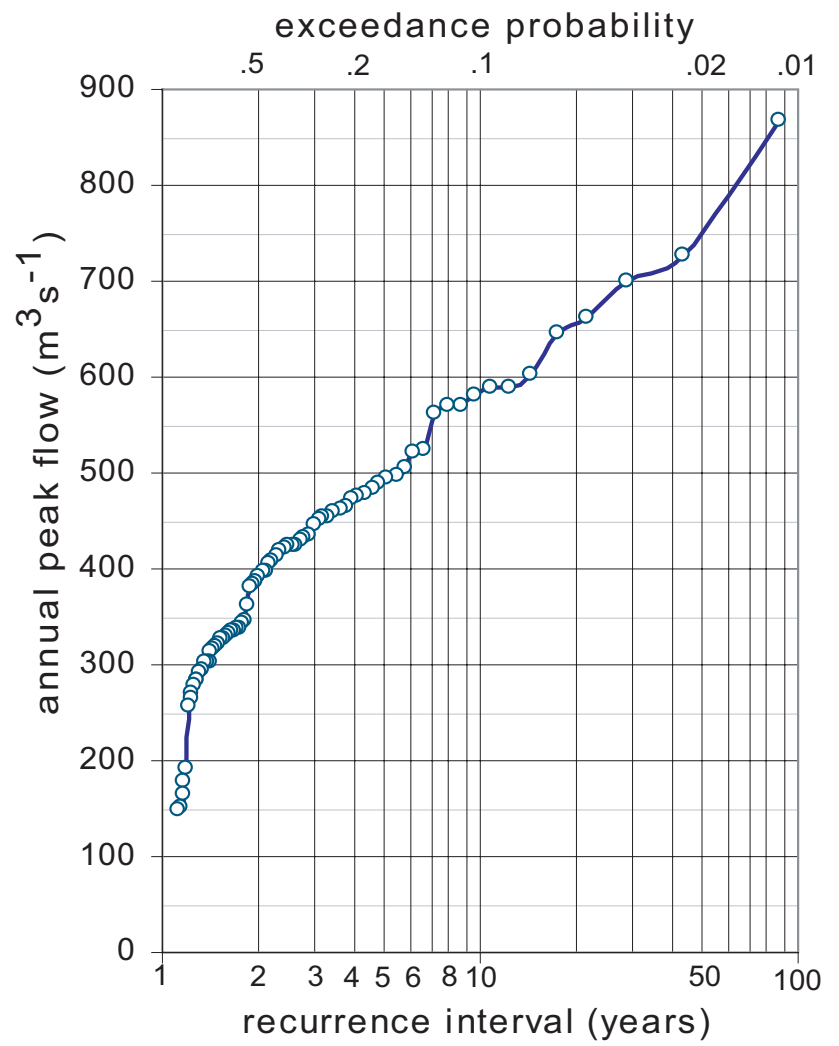

Fig. 6. Flood frequency graph constructed from the 1921 to 2005 record, including the record peak flood flow of $867 \mathrm{~m}^{3} / \mathrm{s}$ of 2005 . From data provided by the Hydrology and Water Management Center for the Upper Northern Region of the Royal Irrigation Department.

possibility of peak flows on the Ping River in excess of the historic record flows should be considered in future studies.

We also estimate the runoff coefficient for the storm as follows. The average storm precipitation for the 19 Royal Irrigation Department stations in the Ping River basin above Chiang Mai for the 27 September-1 October storm is $100.4 \mathrm{~mm}$. Over the $6355-\mathrm{km}^{2}$ basin this precipitation amounts to $638 \mathrm{Mm}^{3}$.

The flood volume of $143 \mathrm{Mm}^{3}$ is calculated from the flood hydrograph beginning at 17:00 on 28 September until 21:00 2 October for flow that exceeds $260 \mathrm{~m}^{3-1}$. This flow is superposed on the already high flow of $260 \mathrm{~m}^{3} \mathrm{~s}^{-1}$ from previous storms (Fig. 5e). This flood volume divided by the storm precipitation volume gives a flood runoff coefficient of $22 \%$.

The Mae Ngad Dam serves as storage for irrigation in the dry season and for flood control of the Ngad River tributary to the Ping River. In a wet year the reservoir is filled to $265 \mathrm{Mm}^{3}$ during the rainy season leaving $35 \mathrm{Mm}^{3}$ for flood control toward the end of the wet season. The dam can release $5 \mathrm{Mm}^{3} \mathrm{day}^{-1}$. When successive storm systems move rapidly across Indochina, as they did in 2005, it is difficult to release enough water from the reservoir before the next flood.

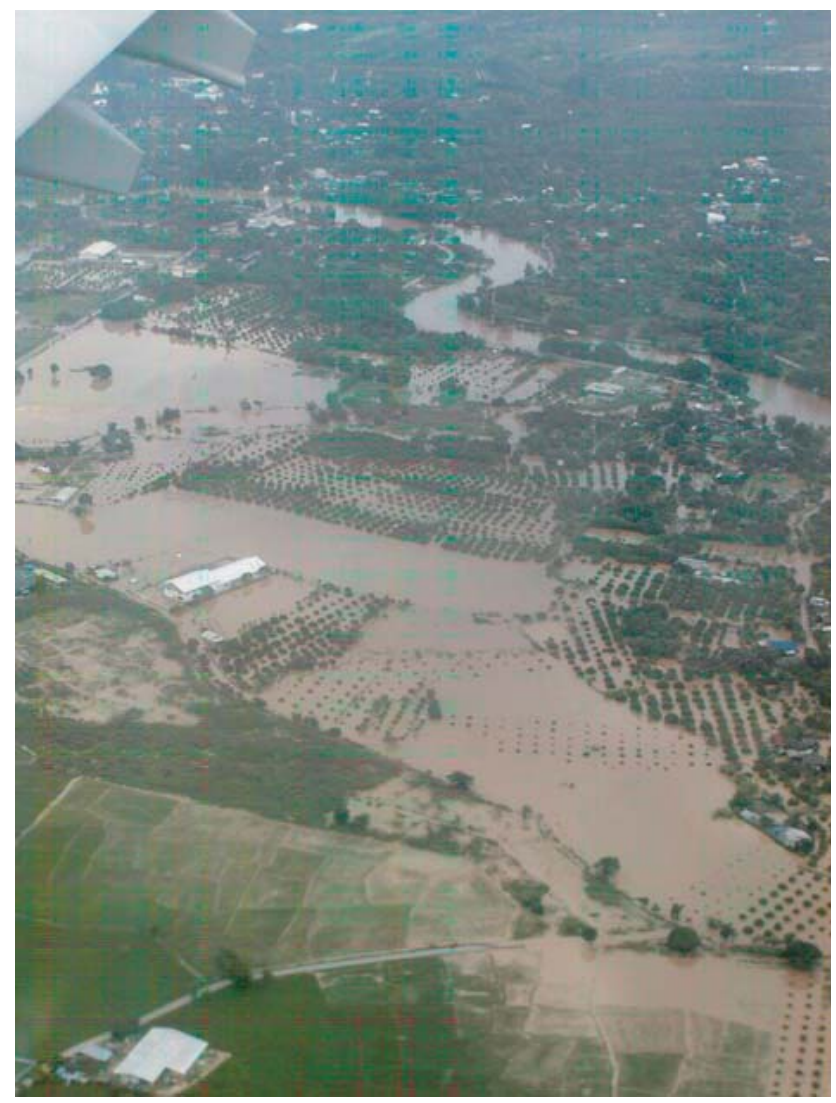

Fig. 7. Photo from airplane of the flooded area of the Ping River at peak flood flow 16:00, 29 September 2005. View is to the east toward the bridge at Ban Mae Kha. Tributary channel joins the river on the right (downriver) side of photo. The village of Ban Ko is along river at the right side of photo. Area of mapped sediment thickness (Fig. 11b) extends from the white building (left center of photo) to the river.

Therefore the reservoir was nearly full when the September storm arrived, and flood control was not possible. Since the 2005 flood experience, the Royal Irrigation Department has greatly expanded its monitoring of regional weather systems and its ability to manage flood flows. Nevertheless, it is a challenge to maintain a reservoir for irrigation demand and for flood control in the monsoon climate of subtropical southeast Asia (T. Sukhapunnaphan, personal communication).

\section{Measurements}

We measured the thickness of wet mud sediment deposited on the floodplain at Ban Ko where the peak flooding was photographed at 16:00 29 September from the window of a commercial aircraft (Fig. 7). On 30 September we took one grab sample of the flood waters to determine suspended sediment concentration. Past measurements of suspendedsediment concentrations were made by the Royal Irrigation 
Department using a US D-49 depth-integrating sampler. Sediment-thickness measurements were made on 2 October, and also on 7 October to cover those areas that were under deep water on 2 October. Our method was to slog through the wet mud-mantled fruit orchards and rice fields and measure soft mud thickness with a millimeter ruler at more than 200 locations over a $0.324-\mathrm{km}^{2}$ area (Fig. 8a). Map locations were determined with hand-held GPS units to $\mathrm{a} \pm 7 \mathrm{~m}$ precision. Where thickness was questionable, the light-brown mud was scraped away to the darker, firmer, gray mud assumed to be the August flood deposit. Sediment thickness was also measured on floors of four elevated bamboo shade huts, where farmers rest in the heat of the day (Fig. 8b). Sediment from the upper part of the water column had settled on these elevated platforms; and therefore, provided information to compare with the sediment thickness on the surrounding ground that received sedimentation from the full water column. We determined the wet density and water content of 6 samples (representative of the slight differences in sediment types over the area) taken at the same time as the thickness measurements. These determinations are used to convert measured thicknesses to equivalent dry sediment. Grain-size analyses were made on the same samples using the sieve and hydrometer method. In the discussions that follow, the names of sediment are based on visual observation at the time of measurement, and confirmed or corrected by later grain-size analyses. In late November, 2 months after the flood, pits were dug and the sedimentary layer was photographed. In March, 2006 an elevation profile (accuracy $\pm 0.05 \mathrm{~m}$ ) was surveyed using a laser level to better understand the pattern of flooding. (Fig. 9).

\section{Results}

\subsection{Sediment concentration}

Total suspended sediment concentration of $1020 \mathrm{mg} \mathrm{l}^{-1}$ was determined from one near-surface sample of the turbulent, muddy, brown floodwaters at Chiang Mai. Sample was taken from 0.2-m deep at the west abutment of Nawarat Bridge near the P.1 gaging station at 16:00 on 30 September. River was in full flood at $840 \mathrm{~m}^{3} \mathrm{~s}^{-1}$ (4.9 m stage). The Royal Irrigation Department took one depth-integrated sample during the 14 August flood, and obtained a value of $1294 \mathrm{mg} \mathrm{l}^{-1}$. These are the largest concentrations measured by the Royal Irrigation Department in their tri-monthly sampling from July, 1993 through August 2005 (Fig. 10). Despite only having two samples at high flow, and knowing little about the sediment-concentration hysteresis pattern of typical large flows in the Ping river, we estimate that the floodwater contained between 1000 to $1300 \mathrm{mg}^{-1}$ of suspended solids when it inundated the study site at Ban Ko.
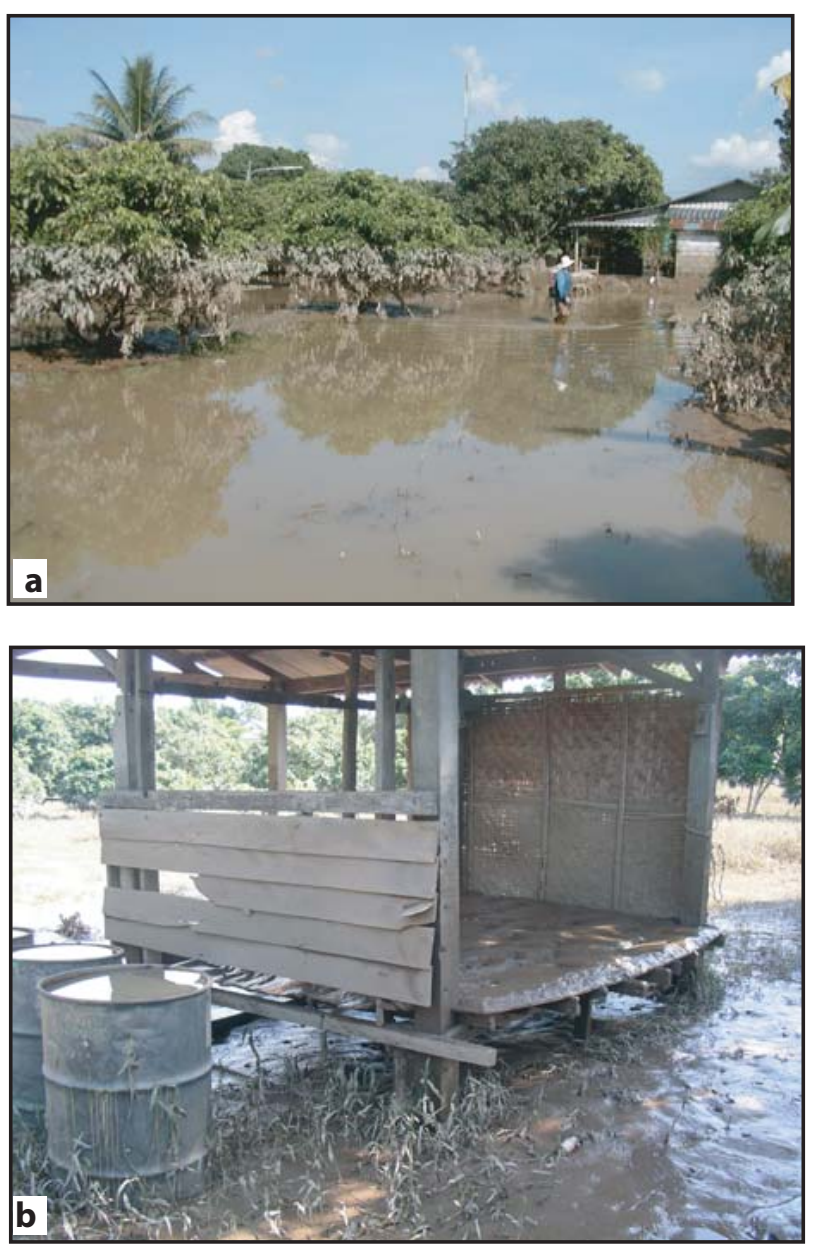

Fig. 8. (a) High water line on fruit trees. Floodwater depth was $1.3 \mathrm{~m}$. Location is at point B of Fig. 11. View is to the southeast. (b) hut located at point $\mathrm{H} 1$ on Fig. 11. Five $\mathrm{cm}$ of sediment deposited on platform elevated $0.55 \mathrm{~m}$ above ground and $8 \mathrm{~cm}$ of sediment on surrounding ground (see Fig. 12). Photos taken on 2 October.

\subsection{Sediment thickness}

Greatest thickness in the Ban Ko study area was $15 \mathrm{~cm}$ of silty-fine-sand sediment along the levee on the north side of the Ping River (Site A, Fig. 11). A pocket of thick sediment was located near the tributary channel. Sediment thicker than $8 \mathrm{~cm}$ covered $16 \%$ of the study area, and extended no more than $250 \mathrm{~m}$ from the main channel. Sediment thicker than $4 \mathrm{~cm}$ covered $44 \%$ of the area and extended no more than $350 \mathrm{~m}$ from the main channel. At a distance of $450 \mathrm{~m}$ from main channel, sediment thickness diminished to $0.5 \mathrm{~cm}$ (Fig. 11). Thickness averaged over the $0.324-\mathrm{km}^{2}$ area is $3.3 \mathrm{~cm}$; this equates to a wet sediment volume of $10700 \mathrm{~m}^{3}$.

Sediment thicknesses were measured on elevated platforms of 4 huts (Fig. 12). Thicknesses on the platforms are an accurate measure of suspended sediment that settled from the upper part of the water column. The bamboo slats on 

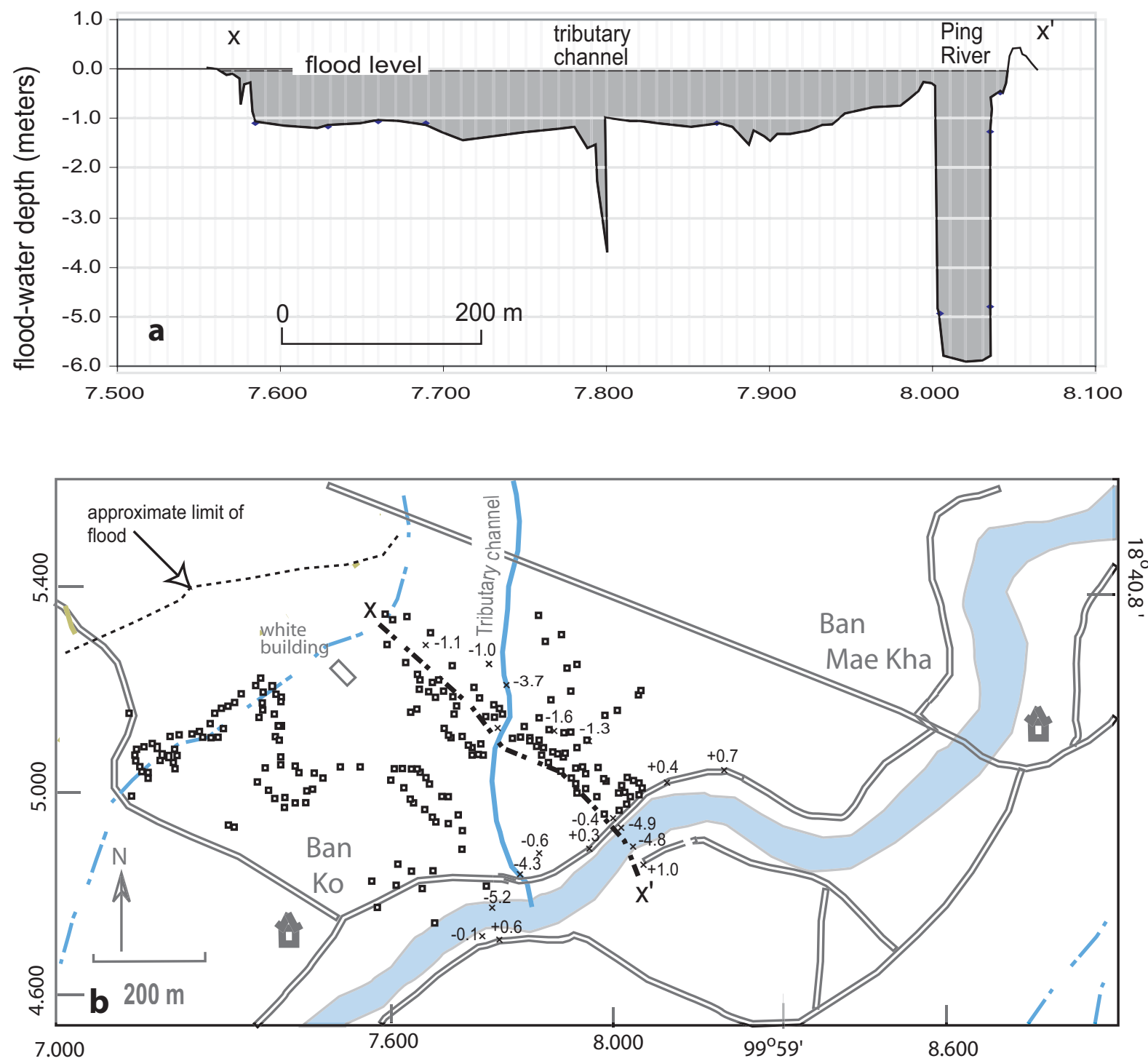

Fig. 9. (a) Elevation profile along line $x-x$ ' showing maximum flood level in area of sediment thickness survey. (b) Map of surveyed ground elevations below maximum flood level and locations of sediment-thickness measurements.

the floors of the huts had a few widely spaced gaps, through which some sediment slumped. However most of the hut floors were covered with a well-preserved even-thickness blanket of sediment, indicating a true thickness was measured. These data indicate that the amount of sediment intercepted by the platform, and that which settled to the surrounding ground was roughly proportional to the thickness of the overlying water column at maximum flood depth (Fig. 12). For example, at hut H2 (Fig. 8b) the flood depth was $1.2 \mathrm{~m}$ over the ground and $0.55 \mathrm{~m}$ over the hut floor, and the sediment thickness was $5.5 \mathrm{~cm}$ and $2.5 \mathrm{~cm}$ respectively (Fig. 12). These observations can be interpreted in two ways: 1) the suspended sediment concentrations were relatively uniform in the water column from which sediment settled, and most of the sedimentation occurred during the 1.8 days when the flood exceeded $700 \mathrm{~m}^{3} \mathrm{~s}^{-1}$ (Fig. 5e). In other words, the water delivered during that time to the point of sedimentation was well mixed from top to bottom. 2) Alternatively, because the flood levels at P.1 gage fell from a peak of $4.9 \mathrm{~m}$, to $4.66 \mathrm{~m}$ in that 1.8 days of maximum depth, the height of water over the platform probably declined $0.24 \mathrm{~m}$, and then after 3 days fell below the level of the platform, and sedimentation on the platform ceased. The ground was still inundated with 0.8 to $0.4 \mathrm{~m}$ of water and sedimentation continued, thus explaining the greater sediment thickness on the ground. 
5.3 Appearance of sediment layers and results of grain-size analyses

When we measured sediment thickness on 2 and 4 October, the flood sediment was mostly soft brown silt overlying distinctly firmer gray colored silt which we presumed to be the pre-flood soil. At the time, we were not aware that this area had been previously flooded during 14-16 August and again partly flooded by the lesser event of 20-22 September. Nor do we have reliable reports on the duration of inundation from these two previous floods. However we believe the brown soft sediment we measured to be only that sediment from the 29 September-2 October flood. Our assumption that the underlying firmer gray sediment was August flood sediment was supported when we excavated and photographed the sediment 2 months later, on 4 December. The now damp firm surface layer was still a brown (7.5 YR) color, and it overlaid gray-colored sediment. The gray-colored sediment (observed in places to be $9-\mathrm{cm}$ thick, in turn, overlaid a thin leaf layer: leafs presumably shed in the previous dry-hot season, February-May, 2005.

Apparently the August flood sediment, over the leaf layer had turned to a gray color (gleyed) within a period of 1.5 months, prior to being buried by the 29 September- 2 October flood sediment. Frequent rains and then the lesser 2022 September flood likely kept the sediment water covered. The gleying process is rapid. Sediment with adequate organic matter consumes available oxygen in flooded soils, and anaerobic microbes then rapidly utilize the one valence of the $\mathrm{Fe}_{2} \mathrm{O}_{3}$ brown-colored oxides to produce $\mathrm{FeO}$ and the resulting bluish gray colors (i.e., the gleying process). Yamanaka and Motomura (1959) experimentally induced soil gleying within 5 to 20 days. Brammer's (1971) studies of soils in Bangladesh showed gleying of the top few inches within two weeks of flooding .

Most of the floodplain sediment is a clayey silt, but a limited number of observations and analyses were made of the variations in texture and stratification. On the levee area within $15 \mathrm{~m}$ of the edge of the channel, $10-15 \mathrm{~cm}$ of massive fine sand and coarse silt was deposited (Figs. 13a, 14). This layer is deposited on a 20-degree slope facing the channel. The relatively coarse texture, thickness, and depositional slope of flood layers deposited on a levee would distinguish levee sediment from other floodplain sediment.

Sediment at point P.1 is composed of basal coarse silt with slight upward fining, $6 \mathrm{~cm}$ thick (Fig. 13b). The textural difference through the layer, deposited $100 \mathrm{~m}$ from the channel, is subtle but it may be detectable as a separate depositional layer in a section of floodplain sediment.

Sediment at Point P2 shows two distinct layers emphasized by drying, shrinking, and parting of the upper layer of clayey fine silt from the lower layer of faintly laminated coarse-medium silt (Fig. 13c). Point P2 is $160 \mathrm{~m}$ from the channel edge. This 7-cm thick layer is so conspicuously layered, it would likely be preserved within floodplain strata.

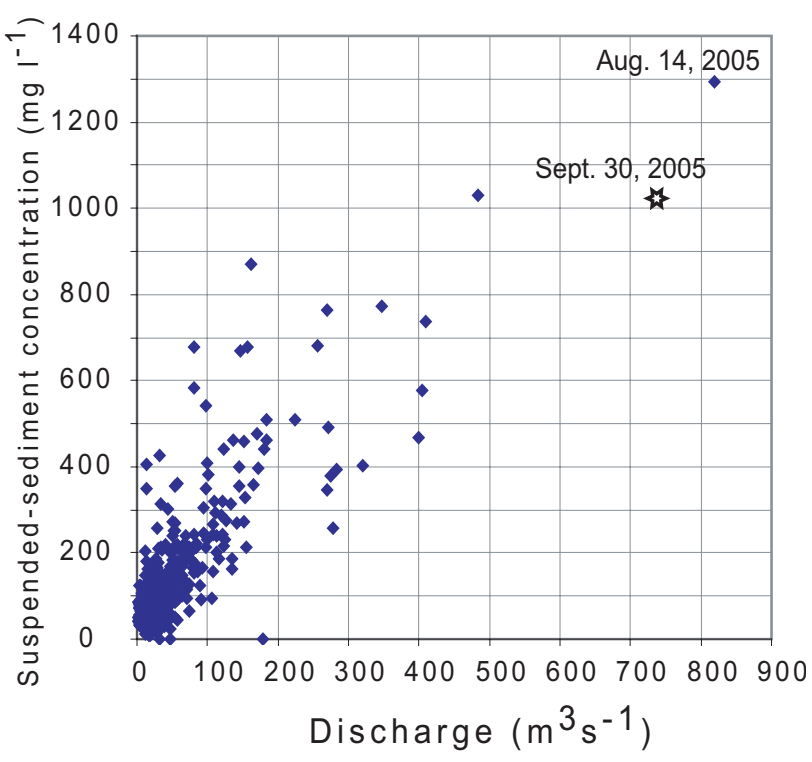

Fig. 10. Suspended-sediment rating data for the Ping River at the Chiang Mai P.1 gage site from Royal Irrigation Department for 1991-August, 2005. Samples obtained monthly and bimonthly using a US D-49 depth-integrating sampler. Shown on the graph are the high values of the one near-surface sample taken on 30 September, and also the one depth-integrated sample taken by the Department during the August 14 flood.

We interpret the lower laminated silt to have settled from the initial surges of moving floodwater into the area; whereas the overlying clayey silt to have settled from slowly moving flood waters.

Sediment at Point B, $200 \mathrm{~m}$ from the channel edge, is $5 \mathrm{~cm}$ of massive clayey silt similar to the upper layer at Point P2 (Fig. 13d). Grain-size analysis shows this sediment to be 28 percent clay (Fig. 14). More distal sediments were massive clayey silt for which grain-size analyses show similar clay content, but finer silt size (Fig. 14).

Although the sample from point E was only $90 \mathrm{~m}$ from the channel edge, it had a fine grain size (Fig. 14) similar to the more distal sediment. Probably irregularities in the floodplain topography isolated this site from moving flood water, so that it received only deposition from slowly moving floodwater.

When we excavated and photographed sediments 2 months after deposition (4 December) we noticed a few tiny tubular holes with orange-colored oxidation rims of 1-2-mm radii in both the brown September sediment, as well as in the gleyed August sediment (Fig. 13b). The holes indicate that macroorganisms had begin to burrow the sediment, ever so slightly. 

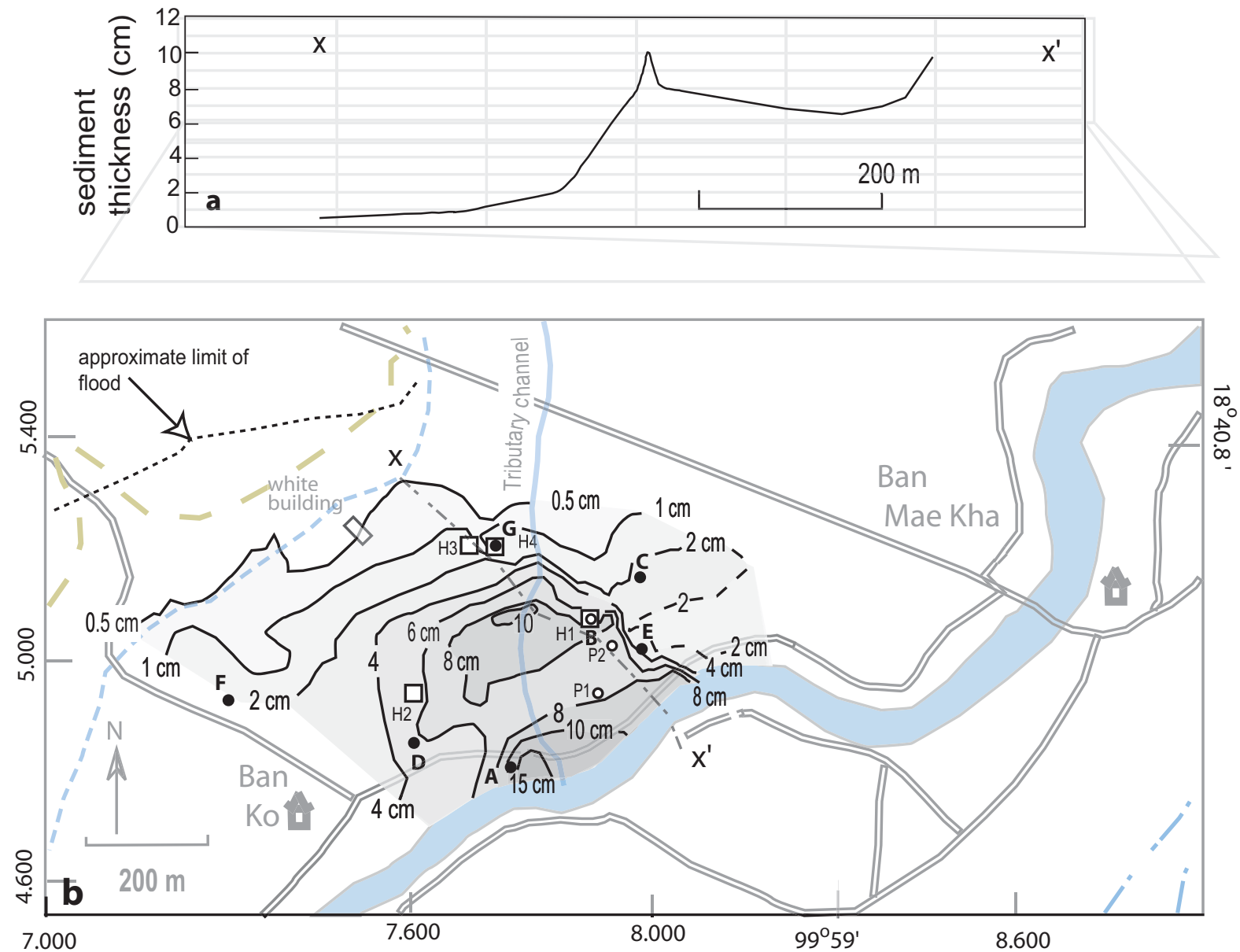

Fig. 11. (a) Profile of wet sediment thickness along line $x-x$ '. b: Isopach map of wet-sediment thickness deposited on floodplain and levee during the 29 September-2 October flood. Points A-G are locations of samples for which grain size analyses are shown in Fig. 14. Points H1-H4 are locations where thicknesses were measured on elevated platforms as well as on the surrounding ground (data shown in Fig. 12). Line $\mathrm{x}-\mathrm{x}$ ' is the line of profiled thickness in Fig. 11a and profiled elevation in Fig. 9b. Photos of sediment are shown in Fig. 13 at locations $\mathrm{A}, \mathrm{B}, \mathrm{P} 1$, and $\mathrm{P} 2$.

\subsection{Density and water content of wet sediment}

Six samples (representative of in-place sediment when the thicknesses were measured) were analyzed for wet density and water content. Density of 5 wet mud samples varied from 1.5 to $1.7 \mathrm{~g} \mathrm{~cm}^{-3}$; and averaged $1.63 \pm 0.10 \mathrm{~g} \mathrm{~cm}^{-3}$. The water content (water mass/mass of dry solids) ranged from 0.52 to 0.83 , and averaged $0.664 \pm 0.14$. Grain size analyses of these samples indicate these mud sediments contained 20 to 40 percent clay (Fig. 14) Excluded from the average is one sediment sample located at point A (Fig. 11) which had a density and water content of $1.86 \mathrm{~g} \mathrm{~cm}^{-3}$ and 0.30 , respectively. This excluded sample which contained more sand than the others (45 per cent fine sand and 17 per cent clay) was deposited on the levee about $15 \mathrm{~m}$ from the channel. The average dry density of sediment is $980 \pm 150 \mathrm{~kg} \mathrm{~m}^{-3}$ calculated from the mean wet density of $1630 \pm 100 \mathrm{~kg} \mathrm{~m}^{-3}$ and the mean water content of $0.664 \pm 0.14$ of the 5 samples.

\subsection{Nature and extent of flooding}

The flooded Ban Ko study area is shown in the 29 September photograph (Fig. 7). Water delivered to this area flowed over the levee on the main channel of the Ping River, as well as up a low-gradient tributary channel-and then most likely set up a weak current over the floodplain area that exited over the levees (Fig. 11). Based on water level stains (Fig. 8a) and the level survey (Fig. 9), the average depth of floodwater in the back-levee area was $1.2 \mathrm{~m}$. Because the bed of the tributary channel grades to the low-water main-channel bed, the tributary channel at flood stage could accommodate flow through a cross section $5 \mathrm{~m}$ deep and $12 \mathrm{~m}$ wide. This particular tributary channel did not have a flood gate, as many channel/canals in the area do. Floodwater overtopping roads did not damage the levees; and no substantial breaches occurred, despite floodwater reaching $0.5 \mathrm{~m}$ over levees at some places. 

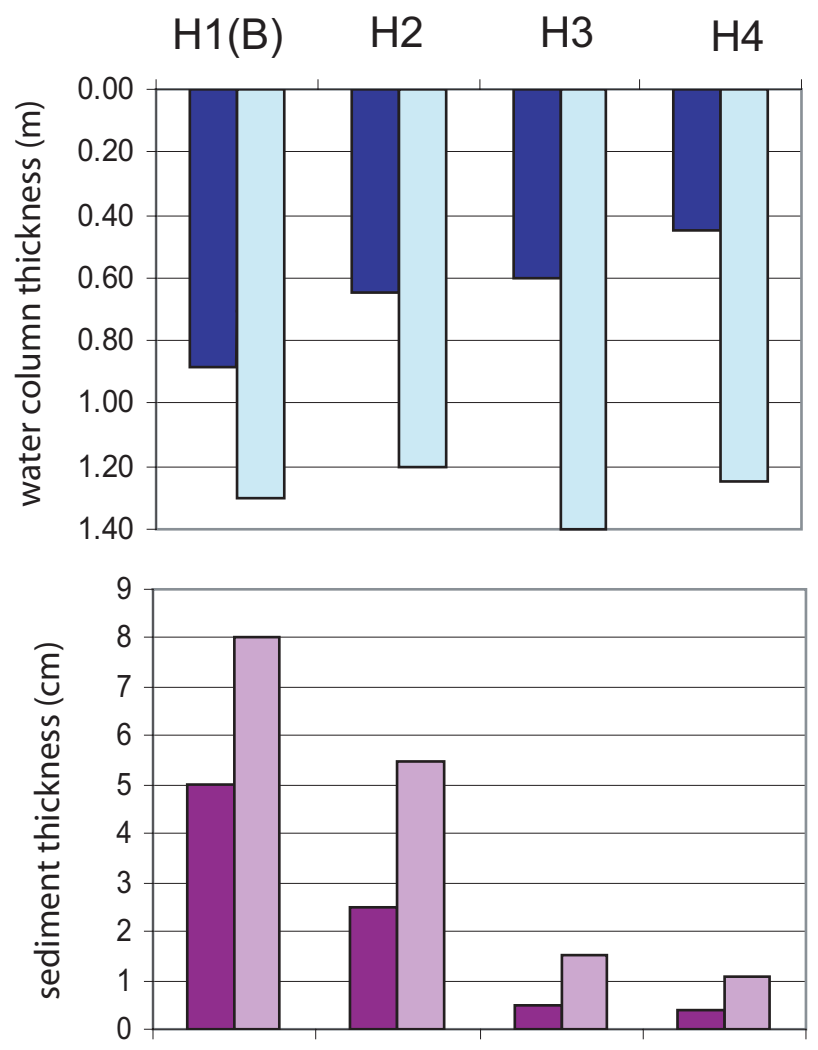

Fig. 12. Upper graph shows thickness of the column of water over elevated platforms (dark pattern) compared to the total depth of water at the site (pale pattern). Sediment thickness deposited on elevated platforms (dark pattern) compared to thickness on the surrounding ground (pale pattern) (Photo of typical hut platform shown in Fig. 8b). Locations of H1(B), H2, H3, H4 shown in Fig. 11.

The greater sedimentation near the tributary channel is similar to that of a crevasse splay, but differs because the channel delivering floodwater to the floodplain was not a breach in the levee, but rather a preexisting tributary channel that graded to the low-water bed of the main channel. This tributary channel delivered mostly silt rather than sand typical of crevasse splay deposits. While the pattern we found at the Ban Ko study area cannot be applied to the whole Ping River floodplain, it can serve as an indicator for areas that were submerged more than $1 \mathrm{~m}$ for similar lengths of time.

Figure 7 shows that the southeast side of the river was not significantly flooded, because the levees were higher and there were no major openings in the levee. In addition, sandbags placed along the road held back some of the floodwater.
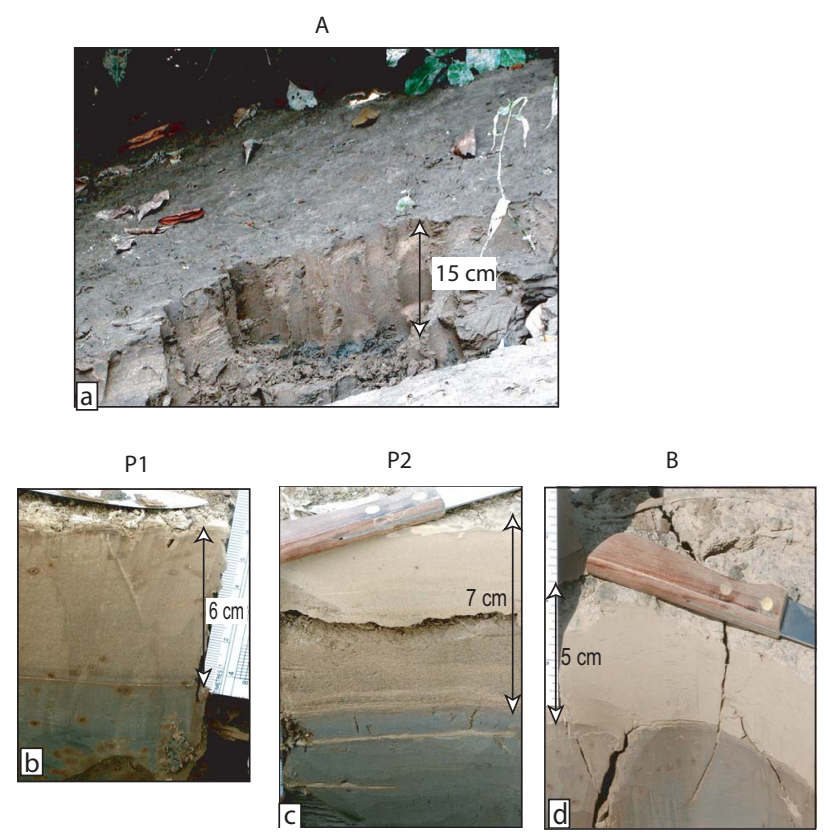

Fig. 13. Photographs of 29 September-2 October sediment at locations A , P1, P2, and B, shown in Fig. 11. (a) River-channel-facing levee deposit on a 20-degree slope at site A. Deposit is $15 \mathrm{~cm}$ of brown silty fine sand (grain-size analysis shown in Fig. 14). October 7 photo. (b) Brown, massive, clayey coarse silt overlying grey clay of the August flood at point, P1, $100 \mathrm{~m}$ from river channel. The 6-cm-thick layer shows slight upward fining, and has developed several tiny rust-stained burrows of macro-organisms when photographed 2 months after deposition. December 4 photo. (c) Sediment shows a basal $3.5-\mathrm{cm}$ layer of brown clayey coarse silt overlain by $3.5 \mathrm{~cm}$ of pale brown clayey silt that has dried and parted from the layer below. The underlying gray August sediment has light-brown silty streaks. 4 December photo at point P2, $160 \mathrm{~m}$ from river channel. (d) Massive 5-cm layer of brown clayey silt at site B, 200 meters from the river channel (Grain-size analysis shown in Fig. 14). 4 December photo.

\section{Discussion}

6.1 Mass of deposit and estimates flood-transported suspended sediment

Approximately $10700 \mathrm{~m}^{3}$ volume of wet sediment was deposited over the $0.324 \mathrm{~km}^{2}$ area.. The volume converts to an average dry-sediment deposit of $32.4 \pm 4.9 \mathrm{~kg} \mathrm{~m}^{-2}$. This amount of sediment requires considerably more than one surge of water over the area. For example, $1.2 \mathrm{~m}$ of floodwater with $1000 \mathrm{mgl}^{-1}$ concentration of suspended sediment would deposit only $1.2 \mathrm{~kg} \mathrm{~m}^{-2}$. Therefore a sustained flow of floodwater must have crossed the area to deliver the $32.4 \mathrm{~kg} \mathrm{~m}^{-2}$ of sediment.

It is informative to estimate the amount of sediment that might have been deposited on the floodplain by the 29 September-2 October flood. The flooded river was not surveyed over the $58-\mathrm{km}$ reach of the Chiang Mai basin that 


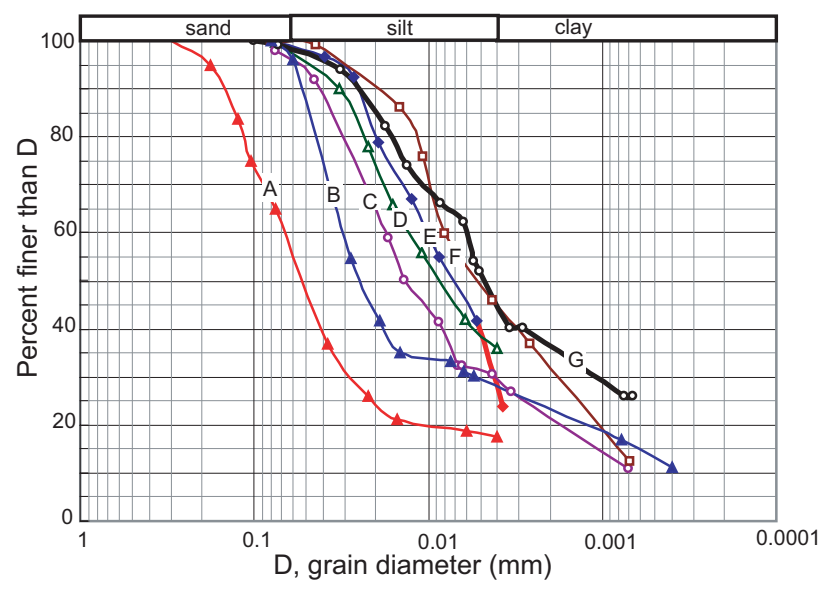

Fig. 14. Sediment grain-size analyses for sample locations shown by points A, B, C, D, G, and F in Fig. 11. Analyses by standard hydrometer and wet-sieving methods.

contains a floodplain. We did observed similar sedimentation of 1 to $8 \mathrm{~cm}$ within low areas of Chiang Mai city, and therefore believe these results are a useful indicator of sedimentation in the extensively flooded areas of the basin. We roughly estimate that a minimum of 5 per cent of the floodplain was flooded similarly out to $500 \mathrm{~m}$ from the channel. From this we estimate $(5 \%) \times(58 \mathrm{~km}) \times(500 \mathrm{~m}) \times(2)=2.9 \mathrm{~km}^{2}$ of the basin was similarly inundated. If sedimentation was similar, then total floodplain sediment would be $\left(5.8 \mathrm{~km}^{2}\right) \times\left(32.4 \mathrm{~kg} \mathrm{~m}^{-2}\right)=93000$ metric tons.

This sediment estimate can be compared to the amount transported by the channel at the P.1 gage by this flood and also to the annual suspended load. Flood flows of 850$600 \mathrm{~m}^{3} \mathrm{~s}^{-1}$ endured for 2.5 days (Fig. 5e). These flows likely carried about $1000 \mathrm{mg} \mathrm{l}^{-1}$ of suspended sediment (Fig. 10). Using $725 \mathrm{~m}^{3} \mathrm{~s}^{-1}$, for 2.5 days, and a concentration of $1000 \mathrm{mg} \mathrm{l}^{-1}$ yields a total of 156600 metric tons transported by the flood through Chiang Mai city.

The 14-year annual suspended-load average (1993-2006) for the Ping River at the P.1 gage is 340800 metric tons per year, but varies from 23700 to 788818 metric tons per year (Royal Irrigation Department, 1993-2006). The estimates above suggest that a significant percentage of the suspended sediment transported in the channel during flood is likely to be deposited on the floodplain; however, we are unaware of flood sediment budget studies on comparable subtropical rivers to better evaluate these estimates. Owens et al. (1999) and Middelkoop and Asselman (1998) determined that about 20 per cent of suspended sediment load transported in floods of European rivers was deposited on floodplain reaches they studied.

\subsection{Comparison with other flood studies}

Floodplain sedimentation is patchy and irregular; and it occurs mostly where channels and unleveed low areas route floodwaters to otherwise leveed areas, and to low areas of the floodplain. Our data generally show the exponential decline in sediment thickness away from the main channel (Fig. 11a). Conveyance of sediment by the tributary channel explains the departure in Fig. 11a from a smooth exponential curve. Exponential decline with distance from channel is reported in other studies of flood sediment (Kesel et al., 1974; Asselman and Middelkoop, 1995; Pizzuto et al., 2008), and long-term vertical accretion deposits (Bridge, 2003). The overall scale of floodplain sedimentation is much less than, but otherwise similar to, that of the April-June, 1973 flood on the Mississippi in Louisiana (USA). For that flood, Kesel et al. (1974) found that sediment thickness and texture decreases away from the river: e.g., $400 \mathrm{~m}$ from the river, sediment thickness was about $2 \mathrm{~cm}$; however sediment depths of 0.5 to $1.0 \mathrm{~cm}$ extended $10 \mathrm{~km}$ away from the channel. Peak discharge of the 1973 Mississippi flood was $42500 \mathrm{~m}^{3} \mathrm{~s}^{-1}$, and large areas were inundated with $4 \mathrm{~m}$ of water for 2 months. Suspended sediment concentrations were not reported.

Gomez et al. (1995) found remarkably small sediment thickness $(<0.4 \mathrm{~cm})$ on leveed and unleveed floodplain areas from the July-August 1993 flood, which had a peak discharge of $12320 \mathrm{~m}^{3} \mathrm{~s}^{-1}$ on the upper Mississippi River. At Keokuk, Iowa this discharge was about $20 \%$ larger than that of the 1973 flood mentioned above. They attribute low sedimentation to relatively low suspended sediment concentrations $\left(<500 \mathrm{mg} \mathrm{L}^{-1}\right)$. However, extensive mud-draped sand deposits up to $30 \mathrm{~cm}$ thick are documented out to $6.4 \mathrm{~km}$ (4 miles) from the channel, at the levee break at Miller City, Illinois (Jacobson and Oberg, 1997).

Similarly, the September 1999 flood associated with Hurricane Floyd, on the Tar River, North Carolina $\left(5654 \mathrm{~km}^{2}\right.$ drainage area), deposited only a thin layer of sediment on the floodplain (Leece et al., 2004). This flood had a peak discharge of $1999 \mathrm{~m}^{3} \mathrm{~s}^{-1}$ and duration of almost 30 days. It was considered the $>500$-year-recurrence flood; and water depth in some floodplain areas was $3 \mathrm{~m}$. Median thickness of fine sediment was $0.09 \mathrm{~cm}$, and the maximum was $1 \mathrm{~cm}$ over the $2-5 \mathrm{~km}$ wide floodplain. They estimated maximum suspended sediment concentrations were less than $465 \mathrm{mg} \mathrm{l}^{-1}$; and the authors attribute small deposition to low suspended sediment concentrations.

Asselman and Middelkoop (1995) report average accumulation rates of $1.6 \mathrm{~kg} \mathrm{~m}^{-2}$ in low lying areas, and 4 or more $\mathrm{kg} \mathrm{m}^{-2}$ on levees for the 3-day 1993 flood on the Rhine and Meuse Rivers in the Netherlands. Suspended sediment concentrations in the floodwaters were less than $400 \mathrm{mgl}^{-1}$.

Near-channel decimeter-thick layers of fine sand and mud from individual floods are reported in studies of the Powder River, Montana by Pizzuto et al. (2008). These floodwaters have enormous suspended sediment concentrations (26000 
to $52000 \mathrm{mg} \mathrm{l}^{-1}$ ). Although not comparable to the Ping River, their studies emphasize the importance of sediment concentration in producing thick layers of flood sediment.

The 2005 flood deposits we found at Ban Ko site along the Ping River are thicker than those usually described in the literature because of greater suspended sediment concentrations, and also because conveyance of the floodwater was not simply overbank flow. Much of the floodwater conveyance to the floodplain at Ban Ko was through a tributary channel; and this allowed thick sediment deposits to occur farther inland than would be expected for only overbank flooding.

\subsection{Flood sediment layers as records of individual floods}

Deposits on the levee were $10-15 \mathrm{~cm}$ thick and were characteristically massive fine-sandy silt. Nearness to the channel suggests minor bedforms in sandy material may occur in these deposits, but we did not observe any bedding. Levee deposits may have a depositional dip up to $20^{\circ}$ if facing the channel, and a few degrees facing the landward side. In a stratigraphic section, these characteristics may useful to identify levee sediments provided the lateral exposure is long enough to see the dip.

A sediment layer thicker than $6 \mathrm{~cm}$ extends in places at least $200 \mathrm{~m}$ from the main channel. In the few excavated and photographed exposures, the flood layer has a visually discernable coarse-silt base and fines upward (Fig. 13b) or has a discrete coarse-silt lower layer overlain by clayey silt (Fig. 13c). This internal structure of a coarse silt base may serve as a guide to individual flood layers, but our observations are too few to determine whether this is a widespread characteristic.

Sediment more distant than $200 \mathrm{~m}$ from the channel is less than $6 \mathrm{~cm}$ thick and composed of massive clayey silt. This part of the flood layer would not be discernable as a separate layer in a stratigraphic section of similar deposits. Sediment in this setting could build up a thick massive layer without internal bedding, yet be the product of many individual flood layers.

Our observations indicate that observable sedimentological features occur in the near-channel deposits that may be useful in interpreting stratigraphic sections of floodplain sediment. In hindsight, we realize that to properly describe the sedimentological nature of an individual flood layer, we would need many transects across the sediment-mantled floodplain with many excavated exposures to document internal structure such as in Fig. 13, as well as sampling and analyses for grain-size. We suggest this for future research when the opportunity to examine a freshly deposited flood layer occurs again.

\section{Conclusions}

Infrequent large floods in northern Thailand occur early or late in the summer rainy season (May-October). Storms that produce large floods are typically associated with tropical depressions that evolve from typhoons in the South China Sea, and then travel westward across the Indochina Peninsula. Along the track of the westward moving depression intense rainstorms (100-200 mm/day) occur in the mountainous areas of northern Thailand.

In 2005, The peak flood flows of the Ping River at Chiang Mai city occurred on August $14\left(850 \mathrm{~m}^{3} \mathrm{~s}^{-1}\right)$, September 21 $\left(725 \mathrm{~m}^{3} \mathrm{~s}^{-1}\right)$, and September $29\left(867 \mathrm{~m}^{3} \mathrm{~s}^{-1}\right)$. Flows above $600 \mathrm{~m}^{3} \mathrm{~s}^{-1}$ lasted for 2.5 days during the 29 September2 October flood. The 29 September peak is considered the 100 -year recurrence flood. Review of flood history and a recent paleoflood study in the adjacent Mae Chaem River basin suggests that peak floods larger than the historic peaks should be considered in future studies of the Ping River drainage.

Floodplain sedimentation was studied over a $0.32-\mathrm{km}^{2}$ area, $12 \mathrm{~km}$ downstream from Chiang Mai, where flooding extended $1 \mathrm{~km}$ from the main channel. Average thickness of wet sediment and mass of dry sediment over the area was $3.3 \mathrm{~cm}$ and $32.4 \mathrm{~kg} \mathrm{~m}^{-2}$. Sediment thicker than $8 \mathrm{~cm}$ covered 16 per cent of the area, and extended up to $250 \mathrm{~m}$ from the main channel. Sediment thicker than $4 \mathrm{~cm}$ covered 44 per cent of the area, and extended no more than $350 \mathrm{~m}$ from the main channel. Sediment thicknesses were also measured on platforms elevated above the ground and compared to sediment thickness on the surrounding ground. Floodwater delivery to this area occurred both by overtopping the levee, and through a gap in the levee at the mouth of a tributary stream. These observed sediment thicknesses are higher than usually reported in the literature for similar relatively shortduration floods elsewhere because of the high suspended sediment concentration in the Ping River, and partly because of flow to the floodplain through the gap in the levee. Available data indicate that flows above $500 \mathrm{~m}^{3-1}$ carry suspendedsediment concentrations of 1000 to $1300 \mathrm{mg}^{-1}$.

Consideration of the amount of sedimentation in the study area, an estimate of the flooded area of the Chiang Mai basin, and the suspended-sediment load carried by the river at flood suggests a significant amount of the floodwater load is sequestered as new sediment on the floodplain of Chiang Mai basin.

Grain-size analyses and later examination of the flood layer showed the following characteristics. Sediment on the levee, $15 \mathrm{~m}$ from the edge of the main channel was $15-\mathrm{cm}$ of massive fine sandy silt. The flood-sediment layer within $200 \mathrm{~m}$ of the main channel was in places thicker than $6 \mathrm{~cm}$ and contained a basal coarse silt, either as a discrete layer or as a fining-upward layer. Beyond $200 \mathrm{~m}$, sediment was a massive clayey silt that would not be discernable as a separate layer in a section of similar deposits. Therefore sediment within $200 \mathrm{~m}$ of the main channel may have sedimentological 
and grain-size characteristics useful in discerning a flood layer in floodplain stratigraphic sections.

In order to better interpret the stratigraphy of floodplain sediments, there is a need for more detailed documentation of the sedimentology of an individual flood layer than was attempted in this study. The photo-documentation and grainsize analyses of the excavated layer was informative and could be done on many transects leading away from the channel. This study has led to an appreciation of the complexity of floodplain sedimentation and identification of some of the variables. Variations in levee height, gaps in levees afforded by mouths of tributary streams, variations in the elevation of the floodplain behind levees, and vegetation cover clearly influence flood depths and the inflow of floodwater to the floodplain. River to river comparisons are influenced by sediment concentrations, grain-size distribution of suspended sediment, and duration of flood. Nevertheless, taking all these factors into account, documentation of a flood layer should prove a useful research endeavor, given the opportunity of another large flood.

Acknowledgements. The authors would like to thank T. Sukhapunnaphan and his staff at the Royal Irrigation Department in Chiang Mai for providing Ping River flow data for this study. We thank T. Bundarnsin and T. Chantaphan for help in the field and lab; and S. Singharajwarapan and F. Singharjwarapan for always helpful discussions and use of lab and office space at the Department of Geological Sciences at Chiang Mai University. The comments of two anonymous reviewers improved the manuscript. We also thank the residents of Ban Ko village for information and hospitality. The study would not have been done properly were it not for the superb view of the flood provided by the pilot of Thai Airlines Flight 923 on September 29. This work was partially supported by grants from the Asia Pacific Network (ARCP2006-06NMY; ARCP200701CMY) and NASA(DS/03-0365-0079).

Edited by: F. Laio

\section{References}

Alford, D.: Streamflow and sediment transport from mountain watersheds of the Chao Phraya Basin, northern Thailand: A reconnaissance study, Mountain Research and Development, 12, 257268, 1992.

Asian Disaster Preparedness Center: Rapid assessment: Flashflood and landslide disaster in the provinces of Uttaradit and Sukhothai, Northern Thailand, May 2006, "available at www. adpc.net/enewsjuly/Uttaradit_rapidassessment.pdf”, 2006

Asselman, N. E. M. and Middelkoop, H.: Floodplain sedimentation: Quantities, patterns and processes, Earth Surface Processes and Landforms 20, 481-499, 1995.

BBC News: Thailand flood kills 70, "available at http://news.bbc. co.uk/1/hi/world/asia-pacific/1487394.stm”, 2001.
Brammer, H.: Coatings in seasonally flooded soils. Geoderma, 6, 5-16, 1971

Bridge, J. S.: Rivers and Floodplains, Blackwell Science, Oxford. 492 p., 2003.

Charuppat, T.: Forest situation in Thailand in the past 37 years (1961-1998) (In Thai), Forest Research Office (Bangkok), Royal Forest Department, 1998.

Gomez, B., Mertes, L. A. K., Phillips, J. D., Magilligan, F. J., and James, L. A.: Sediment characteristics of an extreme flood: 1993 upper Mississippi River valley, Geology, 23(11), 963-966, 1995.

Jacobson, R. B. and Oberg, K. A.: Geomorphic changes on the Mississippi River flood plain at Miller City, Illinois, as a result of the flood of 1993, US Geological Survey Circular 1120-J, 22 p., 1997

Kesel, R. H., Dunne, K. C., McDonald, R. C., Allison, K. R., and Spicer, B. E.: Lateral erosion and overbank deposition on the Mississippi River in Louisiana caused by 1973 flooding, Geology 2, 461-464, 1974.

Kidson, R., Richards, K. S., and Carling, P. A.: Reconstructing the ca. 100-year flood in Northern Thailand, Geomorphology, 70, 279-295, 2005.

Leopold, L. B. and Wolman, M. G.: River channel patterns: braided, meandering, and straight, US Geological Survey Professional Paper 282-B, 39-85, 1957.

Leece, S. A., Pease, P. P., Gares, P. A., and Rigby, C. A.: Floodplain sedimentation during an extreme flood: The 1999 Flood on the Tar River, eastern North Carolina, Physical Geography, 24(4), 334-346, 2004.

Margane, A. and Tatong, T.: Aspects of the hydrogeology of the Chiang Mai-Lamphun basin, Thailand that are important for the groundwater management, Zeitschrift fuer Angevandte Geologie, 45, 188-197, 1999.

Middelkoop, H. and Asselman, N. E. M.: Spatial variability of floodplain sedimentation at the event scale in the Rhine-Meuse Delta, The Netherlands. Earth Surface Processes and Landforms, 23, 561-573, 1998.

Moody, J. A. and Troutman B. M.: Quantitative model of the growth of floodplains by vertical accretion. Earth Surface Processes and Landforms, 25, 115-133, 2000.

Owens, P. N., Walling, D. E., and Leeks, G. J. L: Deposition and storage of fine-grained sediment within the main channel system of the River Tweed, Scotland. Earth Surface Processes and Landforms, 24, 1061-1076, 1999.

Pizzuto, J. E., Moody, J. A., and Meade, R. H.: Anatomy and dynamics of a floodplain, Powder River, Montana, USA, Journal of Sedimentary Research, 78, 16-28, 2008.

Rhodes, B. P., Conejo, R., Benchawan, T., Titus, S., and Lawson, R.: Paleocurrents and Provenance of the Mae Rim Formation, Northern Thailand: Implications for Tectonic Evolution of the Chiang Mai Basin, The Journal of the Geological Society of London, 162, 51-63, 2005.

Royal Irrigation Department (Thailand): Hydrologic Yearbooks, v. 1-49, Royal Irrigation Department, Hydrology Division, Bangkok, 1937-2006.

Sukasem, C. and Chotiwanwilat, S.: Rainfall characterization and zoning of climatic moisture in important river basins of northern Thailand (in Thai with English abstract), Department of Soil Science and Conservation, Faculty of Agriculture, Chiang Mai University, unpublished manuscript, 1987. 
Tangtham, N., Tantasirin, C., and Techamahasarononi, J.: Floods and droughts of the lower Chao Phraya River basin in relation to ENSO events and land use/land cover changes. Paper presented at the 1999 Workshop on GAME-T in Thailand, Kanchanaburi, Thailand, 16 p., 1999.

Thomas, D.,Weyerhaeuser, H., and Saipathong, P.: Improved tools for managing agroforestry landscapes in northern Thailand: Pilot application of spatial analysis and negotiation support systems, in: Xu Jianchu and S. Mikesell, (Eds.), Landscapes of Diversity: Indigenous Knowledge, Sustainable Livelihoods and Resource Governance in Montane Mainland Southeast Asia. Proceedings of the III Symposium on MMSEA, 25-28 August, 2002. Lijiang, P.R. China. Kunming: Yunnan Science and Technology Press, 2002.

Velechovsky, M., Sinthusan, A., and Pitragool, S.: Geological aspects of the burial by flood of the ancient city of Wiang Kum Kam, Chiang Mai, Thailand. Chiang Mai University, Center for the Promotion of Arts and Culture, unpublished report, $18 \mathrm{p}$, 1987.
Wood, S. H., Liberty, L. M., Singharajwarapan, F. S., Bundarnsin, T., and Rothwell, E.: Feasibility of gradient magnetometer surveys of buried brick structures at 13th Century (C.E.) Wiang Kum Kam, Chiang Mai Province, Thailand, in: Proceedings of the International Conference on Applied Geophysics, Chiang Mai, edited by: Rieb, S., Wongpornchai, P., and Chantraprasert, S., Department of Geological Sciences, Chiang Mai University. p. 22-30, available at http://earth.boisestate.edu/home/swood, 2004

Wood, S. H., Ziegler, A. D., and Bundarnsin, T.: Floodplain deposits, channel changes, and riverbank stratigraphy of the Mekong River area at the 14th Century city of Chiang Saen, Northern Thailand, Geomorphology, doi:10.1016/j.geomorph.2007.04.03, in press, 2008.

Yamanaka, K. and Motomura, S.: Studies on the gley formation of soils I: On the mechanism of the formation of active ferrous ion in soils. Soil and Plant Food, 5(3), 134-140, 1959.

Ziegler, A. D., Giambelluca, T. W., Sutherland, R. A., Nullet, M. A., Yarnasarn, S., Pinthong, J., Preechapanya, P., Jaiarree, S.: Toward understanding the cumulative impacts of roads in agricultural watersheds of montane mainland Southeast Asia, Agriculture, Ecosystems, and Environment, 104, 145-158, 2004. 